\title{
Tidsskrift for Forskning i Sygdom og Samfund - 10 år i et krydsfelt
}

\section{Torsten Risør}

Helsevitenskapelig fakultet, UiT Norges arktiske universitet torsten.risor@uit.no

Risør, T. (2015). Tidsskrift for Forskning i Sygdom og Samfund - 10 år i et krydsfelt, Tidsskrift for Forskning i Sygdom og Samfund, nr. 22, 135-149.

Tidsskrift for Forskning i Sygdom og Samfund udkom første gang i begyndelsen af 2005, men var klar til trykning nogle måneder før, så derfor stod der "2004" på forsiden. Med det nummer du nu har i hånden fejrer tidsskriftet derfor sin 10 års fødselsdag, og som ved alle runde fødselsdage kalder det på festtaler, refleksioner og status over tiden som er gået og måske en morsom anekdote eller to om fødselaren.

Men inden dette bliver ren festtale og løssluppen morskab, har vi i redaktionen også lyst til at bruge dette som en mulighed for lidt analytisk eftertanke. På den ene side ønsker vi at diskutere om tidsskriftet bevæger sig i den retning, som vi oprindelig ønskede, og om vi har opnået noget at det, som vi ville opnå. På den anden side er tidsskriftet del af større bevægelser i sundheds- og samfundsvidenskab, og det kan være nyttigt at overveje i hvilket omfang, tidsskriftet bliver et billede på disse bevægelser. Det er altså både tidsskriftet som handlende subjekt og som objekt for påvirkning udefra, som vi har lyst til at bruge lidt tid på. 


\section{Historien om et tidsskrift}

Det var en dag i efteråret 1999. Mette fortalte Torsten, at hun havde snakket med Bjarke. Mette og Bjarke var enige om, at der var brug for at samle de mange forskningsaktiviteter som bevægede sig i feltet mellem sundhedsvidenskab og samfundsvidenskab i Danmark. De havde diskuteret, om de skulle starte et nyt tidsskrift. Jens havde også sagt ja til at være med, og de ville også gerne have Hanne med i redaktionen. Torsten sagde, at det lød som en god ide, men skulle de ikke have en læge med - og gerne en som vidste noget om antropologi i forvejen? Dermed var de fem medlemmer fundet i det som skulle blive den første redaktion for Tidsskrift for Forskning i Sygdom og Samfund: Mette Bech Risør, Bjarke Paarup Laursen, Jens Seeberg, Hanne Mogensen og Torsten Risør.

Det var på en måde begyndelsen, men en vigtig forhistorie ligger i Suppleringsuddannelsen for Medicinsk Antropologi ved Institut for Antropologi og Etnografi ved Aarhus Universitet. Denne 1-årige uddannelse - som senere skulle blive en egentlig masteruddannelse - var startet i 1996 og havde hvert år omkring 30 studerende fra sundhedsprofessionerne (+ enkelte andre fag) som var interesseret $\mathrm{i}$ at lære social antropologi og særligt medicinsk antropologi. Både Mette, Bjarke og Jens havde været ledere af uddannelsen og havde set, hvordan der opstod projekter, blev skrevet spændende opgaver, blev etableret nye samarbejder som følge af uddannelsen. Var tiden moden til at give disse projekter en base at præsentere sig på?

På de første møder diskuterede vi i den første redaktion alt fra det principielle - er der brug for et tidsskrift, hvad skal formålet være - til det mere generelle hvem skal læse det, hvordan finansieres et tidsskrift, hvor ofte skal det udkomme - og til det specielle om, hvordan vi søger penge, hvornår er næste møde, og hvilke opgaver skal løses. Fra disse første møder - på Moesgård ved Århus, på Institut for Antropologi i København og ikke mindst til aftenmøder hjemme hos redaktørerne privat - udvikledes ideerne og rammerne. På næste side står det som blev vores første dokument som beskrev tidsskriftets ide, ønsker og målgruppe. Artiklen diskuterer senere, hvordan det er gået med målene og ønskerne for tidsskriftet fra dengang. 


\section{Baggrund for tidsskriftsidéen}

Vi mener, at der i danske forskningssammenhænge er behov for at skabe et medie til formidling af det tværvidenskabelige felt medicinsk antropologi. Medicinsk antropologi forstås her som et felt, der ikke blot er knyttet til faget antropologi, men som ofte i bred forstand engagerer alle de forskellige faggrupper (sygeplejersker, psykologer, antropologer, læger, pædagoger m.fl.), der arbejder med sundhed og sygdom. Disse faggrupper indgår $i$ de mange forskellige initiativer, som er i gang eller er ved at komme i gang inden for feltet $i$ Danmark: Nye uddannelser på universiteter og sygeplejeskoler samt forskningsenheder og centre, der arbejder tværfagligt omkring særlige sygdomsfænomener, behandlingsformer eller sundhedsfremme. Alle disse initiativer kan have brug for et fælles medie til at hjælpe sig i processen med at definere feltet, til at fremme samarbejdet mellem de mennesker, der arbejder i feltet, og til at åbne for samarbejde med beslægtede fagområder.

Et tidsskrift vil på denne baggrund have til formål at formidle forskning, der ligger i grænsefeltet mellem sundhedsvidenskab og antropologi og at fungere som et forum, der binder disse fag sammen, hvor de konkret mødes og inspirerer hinanden- epistemologisk, metodisk eller teoretisk - i forskellige forskningssammenhænge.

Tidsskriftet ønsker:

1) at formidle medicinsk antropologi, der er relevant i en bredere sundhedsmæssig sammenhæng.

2) at formidle anden faglig forskning, der bidrager til diskussioner inden for det medicinsk antropologiske interessefelt.

3) at udkomme overvejende som temanumre, evt. med enkelte selvstændige artikler udvalgt af redaktionen.

4) at sammensætte temanumre således, at temaet belyses fra forskellige faglige vinkler $i$ henhold til a) og b).

5) at formidle forskning på højt fagligt niveau med peer reviews, der understøtter det tværfaglige formål.

\section{Målgruppe}

Målgruppen for tidsskriftet vil være alle med interesse for det medicinsk antropologiske forskningsfelt, men typisk vil det være sundhedsfolk i forsknings- eller undervisningssammenhænge med forbindelse til tværfaglige miljøer. Det er desuden intentionen at åbne op for et skandinavisk netværk både med hensyn til bidrag til tidsskriftet og læserskare. 
Ingen af os i den første redaktion havde erfaringer med at starte et tidsskrift, så der ventede os en lang læreproces, som det er vanskeligt at finde vejledning for. Herunder: Hvad koster det egentlig at udgive et tidsskrift, og hvordan skaffer vi de penge? Vi ønskede, at det skulle finansieres gennem abonnement og løssalg, men først måtte der være noget at abonnere på, så vi havde brug for økonomi til at komme i gang.

I 2000 fik vi etableret en forening for tidsskriftet. Dette var nødvendigt for at kunne søge Humanistisk Forskningsråd om støtte til at oprette og drive tidsskriftet. Mødet, hvor foreningen blev etableret, blev afholdt på Moesgård, og Gitte Wind blev ved mødet valgt som sjette redaktør i gruppen, og Mette blev chefredaktør. Tilsammen repræsenterede vi miljøer i København og Århus, både antropologi og sundhedsvidenskab, og vi tænkte, at det var vigtigt for at have et større netværk og lettere adgang til at finde aktuelle temaer og mulige forfattere.

Men støtte fra forskningsrådet krævede også, at vi kunne vedlægge to fuldt færdige numre af tidsskriftet. Vi var landet på, at ca. 6 artikler per nummer på hver ca. 20 sider var et passende omfang. Så vi måtte få 12 forfattere til at skrive artikler til et tidsskrift som endnu ikke fandtes!

Vi sendte invitationer, skrev breve, overvejede hvad vi selv kunne skrive og det tog tid. Men i løbet af de næste år fik vi tilsagn fra forfattere, fik de første versioner af artikler, gennemførte en slags peer review med redaktionen som reviewere og havde til sidst 2 sæt artikler, så vi kunne søge - og få! - støtte til at trykke de første numre og mulighed for at sende ny ansøgning til senere udgivelser. I første nummer fik vi lov til at bringe en artikel af Byron J. Good (som vi oversatte til dansk), men ellers var alle artikler nye. Fra redaktionen skrev Bjarke, Hanne, Jens, Mette og Torsten artikler til nr. 1 og nr. 2. Men vi var helt afhængige af, at der var andre som troede på ideen og kunne finde tid til at skrive originalartikler. Tak til jer som troede på os og skrev artikler til et tidsskrift som ikke fandtes: Kirsten Hastrup, Susan Reynolds Whyte, Frede Olesen, Helle Ploug Hansen, Cheryl Mattingly, Anders Ingemann Larsen, Jørgen Riis Jepsen og Vibeke Steffen.

\section{Redaktionen 2005-2015}

Så var vi i gang, og det betød også, at vi måtte holde os i gang. Indtil da havde vi holdt møder, når det passede, indimellem var der gået flere måneder mellem møder, og det kunne være lidt vanskeligt at holde energien og engagementet oppe. Vi havde trods alt alle en travl hverdag, hvor dette ikke var en central opgave. Eksem- 
pelvis skulle Mette afslutte sin ph.d. i 2002, og Torsten og Mette blev forældre til Rebekka i 2000 og Silas i 2002, og de fleste møder måtte holdes hjemme hos Mette og Torsten, så børnene kunne puttes inden mødet. I flere år var "redaktionslokalet" derfor stuen og køkkenet på Ågade 2 i Spørring. For artiklerne i tidsskriftet de sidste 10 år gælder det generelt, at de demonstrerer, hvordan sygdom er en social, situeret og kompleks proces. Det samme kan siges om arbejdet med at skabe et tidsskrift.

Nu måtte vi altså, fra 2005, holde regelmæssige møder - det blev 1 gang hver måned - og vi måtte sørge for, at processen fra invitation til trykt artikel blev holdt i gang. Et nyt tema skulle findes næsten 2 år før, det kom på tryk. Først blev vi overrasket over det, men det kan egentlig ikke reduceres så meget, da vi havde brug for tid til alle delprocesser: finde et tema, skrive en invitation til forfattere, give god tid til forfattere til at skrive, modtage og vurdere første version, evt. sende retur til forfatter, vurdere på ny, finde reviewere, sende i review, give reviewere tid til at læse og vurdere, modtage og vurdere review, sende svar til forfatterne, give tid til at revidere manus, modtage ny version, evt. sende i review igen, vurdere endelig version, korrekturlæse, sætte op og sende til trykkeriet. Ting tager tid.

Der er flere vigtige milepæle i redaktionens arbejde fra 2005 til 2015. Fra temanummer 6 fik vi etableret peer review med anonymisering og 2 reviewere for hver artikel. Dette var, som man kan se på vores ønskeseddel helt fra den tidlige idefase. Indtil 2007 havde redaktionen gennemført en form for review, hvor vi alle læste alle artikler og diskuterede alle artikler. Og gentog det igen, når nye versioner af artiklerne forelå. I 2007 kom vi med i et projekt på Statsbiblioteket i Århus som førte til, at vi blev et elektronisk tidsskrift samtidig med, at vi fortsatte med at udkomme i papirformat (mere om det nedenfor). Først med delvis og siden med fuld open access til artiklerne. I 2010 flyttede to af redaktørerne til Tromsø i Nord-Norge, og det betød en effektiv afslutning på månedlige møder. Men på det tidspunkt var der også kommet en vis rutine i processerne, så vi kunne nøjes med halvårlige eller årlige møder - i Århus, København eller Tromsø - samt en omfattende kommunikation på email, telefon og skype.

Redaktionen skiftede lidt besætning undervejs, men forsøgte at fortsætte med at have en redaktion som både geografisk og fagligt havde spændvidde for at kunne have et bredt kontaktnet og variation i mulige temaer. Lisbeth Ørtenblad kom med i 2004 i stedet for Jens Seeberg og sluttede i 2007 med at lede arbejdet med temaet "Søgen efter helbredelse", det største nummer blandt de første 6. Omtrent samtidig sluttede Hanne Mogensen, og hele fire nye redaktører kom ind - Marianne Rosendal, Peter Vedsted, Lotte Meinert og Tine Tjørnhøj-Thomsen. Tine blev 
erstattet af Helle Max Martin i 2008, som igen blev afløst af Ann Dorrit Guassora i 2009. Bjarke Paarup som havde været med helt fra ideen blev tænkt, gik ud af redaktionen i 2009 og Susanne Reventlow kom ind. Marianne Rosendal gik ud i 2010, og Lotte Meinert og Peter Vedsted i 2011. Rikke Sand Andersen kom med fra 2010 og Claus Bossen fra 2011. Redaktionen har fra 2011 været stabil - Mette, Torsten, Gitte, Ann Dorrit, Susanne, Rikke og Claus er fortsat med i redaktionen. Dog var Helle Ploug Hansen med i 2013 og blev erstattet af Helle Max Martin som kom tilbage i redaktionen samme år.

Redaktionen har således været rimelig stabil i sammensætning og størrelse gennem hele tidsskriftets levetid og har hele tiden haft medlemmer fra både samfunds- og sundhedsvidenskab og fra både Øst- og Vestdanmark. Alle de redaktører, som ikke længere officielt er i redaktionen, har haft redaktionelle opgaver - som gæsteredaktører og reviewere - senere, så på den måde er der også blevet en større kreds af ressourcepersoner, som er med på projektet og kan bidrage, når der er brug for det. Arbejdsmængden for den enkelte redaktør - med undtagelse af chefredaktøren - er nu også betydelig mindre end i de tidligere år, og vi kan koncentrere arbejdet om de faglige opgaver - at vurdere manuskripterne som sendes ind og sikre, at de får en solid faglig vurdering.

Vi har også haft en del gæsteredaktører undervejs. I nogle tilfælde har vi inviteret gæsteredaktører, som vi vidste, kunne bidrage med viden om et felt, som vi selv var lidt usikre på, men som så ud til at kunne blive til et spændende tema. I andre tilfælde er vi blevet kontaktet med ønsker om et bestemt tema, eller hvor en konference ville give mulighed for at invitere forfattere som havde en fælles tematik, som de var interesseret i. Første gang vi prøvede det var med Katrine Schepelern Johansen og Charlotte Bredahl Jacobsen på "Humanistisk Psykiatri i 2006. Anette Sonne Nielsen var gæsteredaktør på "Etniske minoriteter og sundhedssystemer" i 2007. Siden 2010 der været 1 eller flere gæsteredaktører på de fleste temanumre. I 2010 var Mette Asbjørn Neergård gæsteredaktør på "Tæt på døden" og Marie Østergaard Møller og Lise Kirstine Gormsen på "The role of chronic pain and suffering in contemporary society". I 2011 var Birgit H. Petersson med på "At spise", og samme år var der hele tre gæsteredaktører på "Kvalitative perspektiver på evalueringer i sundhedsvæsenet": Kåre Jansbøl, Katrine S. Johansen og Marius B. Kousgaard. Claus Vinter Nielsen var med på "Arbejde" og Nanna Mik-Meyer og Anne R. Obling på "Sundhed". Endelig var Anne R. Obling (igen) og Stinne A. Ballegaard med på hver et tema i 2014; henh. "Tid og kræft" og "Telemedicin".

Fra starten blev det klart, at det at have gæsteredaktører med var en styrkelse, ikke bare i den faglige bredde, men også i nuanceringen af temaerne og i mulighe- 
derne for at finde mulige forfattere. Selvfølgelig kan der være lidt vanskeligheder i det at arbejde med den redaktionelle proces, men som sagt var en del processer blevet mere systematiseret $\mathrm{i}$ løbet af årene, så jeg tror de fleste gæsteredaktører har oplevet, at det har været en opgave, hvor det faglige arbejde med at beskrive og udvikle temaet og vurdere artiklerne har været det centrale.

En væsentlig grund til at det faglige i redaktionsarbejdet kom mere i centrum var, at logistikken i høj grad blev håndteret af vores skiftende redaktionssekretærer på Moesgård. Det er antropologi-studerende som i en periode har haft denne rolle og har holdt styr på abonnementer, korrekturlæsning, kontakt med tegnestue og trykkeri, opdatering af hjemmeside med mere. Hanne Boll Overgaard var vores første sekretær i 2004-2005. Hun blev afløst af Linda Vorm Hellegaard som var en solid støtte for os i perioden 2005-2008 og altså med i processen med at få antal abonnenter op og gå over til OJS (Statsbibliotekets online journal system). Malene Nielsen tog over i en periode i 2008, og blev afløst af Thomas Christian Mikkelsen som sad i stolen helt til 2013 og gennemførte flere forbedringer af vores rutiner med tidsskriftet. Stine Haslund Jønsson har de seneste år været vores solide arbejdskraft på Moesgaard, men er nu netop sluttet og er blevet afløst af Louise Ormstrup Vestergård.

\section{Temaer og artikler - lidt statistik}

Lad os nu se på lidt statistik og temaer for tidsskriftet: Der er nu kommet i alt 21 numre af Sygdom og Samfund med tilsammen 161 artikler, skrevet af 143 forfattere. Tabel 1 viser en oversigt over numrenes temaer, inklusiv udgivelsesår, antal artikler og antal sider i nummeret. Vi har i valg af temaer hele tiden diskuteret, hvilke temaer som kunne være interessant at samle i et nummer, hvilke temaer som var på vej frem og kunne styrkes gennem en fælles udgivelse og - mere pragmatisk - hvilke temaer som faktisk kunne tiltrække så mange forfattere, at det ville være muligt at skrive om. Det viser sig også i temaerne, at der både er valgt temaer som er centrale i medicinsk videnskab $(8,9,12,20)$, temaer som kan siges at ligge i udkanten af medicinsk forsknings interesse $(4,5,6)$ og temaer som kaster et kritisk analytisk blik på sundhedsvæsenet i bred forstand $(3,11,13,15,17)$, og så er der temaer som tager sit udgangspunkt i hverdags praksis $(11,14,16)$ eller ser på sundhedsvæsenets opbygning og forandringer i det (1, 18, 21). Endelig er der temaer, som tager analytiske og metodologiske perspektiver fra antropologien som sit afsæt $(2,10,19)$. 


\section{Tabel 1 - Temaer (årstal) - antal artikler, sidetal}

1) Positioner (2004) - 6, 135

2) Narrativer (2005) - 6, 120

3) Sundhedsfremme og forebyggelse (2005) - 6, 119

4) Humanistisk psykiatri - udforskning af et krydsfelt (2006) - 8, 153

5) Somatisering? - sygdom uden forklaring (2006) - 8, 155

6) Søgen efter helbredelse - om alternative tilgange (2007) - 8, 163

7) Etniske minoriteter og sundhedssystemer (2007) - 6, 112

8) Epidemier (2008) - 8, 126

9) Kronisk sygdom (2008) - 6, 122

10) Metodologi (2009) $-7,136$

11) Krop og teknologi (2009) - 8, 140

12) Trt på døden (2010) - 9, 188

13) The role of chronic pain and suffering in contemporary society (2010) - 9,208

14) At spise - ikke kun et spørgsmål om mad (2011) - 7, 136

15) Kvalitative perspektiver på evalueringer i sundhedsvæsenet (2011) - 8, 176

16) Arbejde - sundhed og sygdom (2012) - 8, 186

17) Sundhed - en ny semi-religiøs vakkelse i det moderne samfund (2012) - 8, 172

18) Sygdommens rum (2013) - 8, 171

19) Culture or nature - paradoxes of agency (2013) - 6, 148

20) Tid og kræft (2014) - 8, 176

21) Telemedicin (2014) - 7, 142

Antal artikler varierer fra 6-9 med 8 som det mest almindelige (10 ud af 21 numre). Der er en tendens til at der bliver flere artikler i løbet af de 10 år: Mens 5 numre fra 1-10 kun havde 6 artikler, har der kun været 1 nummer med 6 artikler siden da, og de to numre med 9 artikler er fra 2010. Antal sider varierer da også fra 112-208 med en tendens til stigende sidetal. Således var gennemsnittet på 134 sider for de første 10 numre, men 167 sider for de følgende 11.

De fleste artikler har kun 1 forfatter (114), men artikler med 2 (35) eller endda 3 (11) eller 4 (1) forfattere forekommer også. Det gennemsnitlige antal forfattere for de 161 artikler er 1,37 per artikel. Men hvor det for de første 3 numre er 1,17, er gennemsnittet 1,38 for de sidste 3 numre. Det er en bevægelse i retning af flere forfattere som også ses for anden samfundsvidenskabelig forskning, og i TFSS ofte er resultat af, at projekter bliver udført i et samarbejde mellem flere forskere, typisk med forskellig faglig baggrund. 


\section{Forfatterne}

Tidsskriftets forfattere er helt overvejende fra Danmark. Dette er ikke overraskende. Alle redaktører var fra starten danske, og det var en ambition for tidsskriftet at prøve at skabe forbindelse mellem de danske forskere med beslægtede interesser i det medicinsk-antropologiske felt. I hvert af de første to numre var der en amerikansk artikel, henholdsvis fra Boston og fra Los Angeles. Good-artiklen var tidligere trykt og blev bragt med tilladelse til genoptryk, mens Mattinglys artikel var inviteret og sandsynligvis var med til at give lidt mere opmærksomhed på de første numre. Men ellers var det overvejende danske forfattere, og det endda helt overvejende forskere fra bare to universitetsområder - København og Århus.

Dette ændrede sig gradvis. Norge blev hurtigt repræsenteret, sådan at der kom artikler fra Kristiansand (nr. 4, 16), Bergen (nr. 5), Gjøvik (nr. 11), Oslo (nr. 14), Tromsø (nr. 16, 21) og Bodø (nr. 21). Sverige har også været med i flere temaer med artikler fra Stockholm (nr. 5, 20) og Malmø (nr. 7). Desuden kom der artikler fra lande uden for Skandinavien. Udover de to amerikanske artikler i starten var der tekster fra England (nr. 4, 17), Indien (nr. 8), USA (nr. 13), Schweiz (nr. 19) og Finland (nr. 19).

Også i spredningen i miljøer indenfor Danmarks grænser viser der sig en udvikling henover de ti år. I de første 4 numre var der eksempelvis 10 forfattere fra Århus, 11 fra København og bare 2 fra Odense. Men derefter begyndte også andre forskningsmiljøer i Vejle, Roskilde, Odense og - især - Ålborg at blive godt repræsenteret. I de sidste 4 numre er der således hele 11 forfattere fra Ålborg. Til sammenligning var der i de sidste fire numre 5 forfattere fra Århus, 6 fra København og 1 fra Odense.

En tilsvarende - og endnu tydeligere - forandring i retning af diversitet kan vi se i de fagligheder, som forfatterne repræsenterer. I de første to numre skrev 10 antropologer og 4 læger, og ingen andre. Men allerede i de næste to numre var der forfattere fra sygepleje, religionsvidenskab, pædagogik, historie og journalistik. Senere har der været flere artikler med disse faglige udgangspunkter samt bidrag fra filosofi, idehistorie, sociologi, kønsstudier, arkitektur, levnedsmiddelstudier, teologi, computervidenskab, ingeniørkunst, organisationsstudier, statskundskab og psykologi.

Der har ofte været 1-2 læger blandt forfatterne i et tema, og de har repræsenteret både almen medicin, arbejdsmedicin, infektionsmedicin, psykiatri, gynækologi, obstetrik, socialmedicin, palliativ medicin og ortopædkirurgi. Imidlertid har der - af en eller anden grund - kun været 2 læger blandt forfatterne i de sidste 5 num- 
re. I de samme 5 numre har der også kun været én forfatter med baggrund som sygeplejerske. Både medicin og sygepleje var stærkere inde i de første årgange, og man kan overveje hvorfor. Det er muligt, at vi med valg af tema har flyttet os fra studier, som udspiller sig i de kliniske rum med de sundhedsprofessionelle som centrale aktører og ud i rum og temaer, som strækker sig udenfor sygehusene og lægehusene. Ser vi på temaerne (tabel 2), så ser det ud til, at der er noget om det. I løbet af årene har vi udvidet fokus til nye rum, en udvidet forståelse af sundhedssystemers grænse kan man sige, og har taget udgangspunkt steder som er vigtige for sygdom og sundhed - krop, rum, mad, arbejde - men som i mindre grad er omdrejningspunkt for sundhedsprofessionelles forskning. Eller vi har taget et kritisk perspektiv på sundhedssystemer udefra; også på de aktiviteter som var mere politisk styrede som evalueringer og sundhedsfremme, og hvor de sundhedsprofessionelle ofte oplever sig sat udenfor indflydelse; måske oplever de også at disse aktiviteter ikke angår dem i samme grad, da kerneydelsen for læger, sygeplejersker og fysioterapeuter fortsat opleves at være den individuelle kontakt med en person, som har et konkret sundhedsproblem som skal håndteres.

Betyder det, at der er risiko for, at vi ikke længere taler til de sundhedsprofessionelle med tidsskriftet? Måske. Men modsat kan man sige at TfSS gennem invitationen af professioner som ikke normalt opfattes som del af sundhedssystemerne kan præsentere nye temaer og bevægelser i og omkring patientbehandling og sundhedsvæsen, som ellers er svære at få oversigt over som læge eller sygeplejerske. Vi i den nuværende redaktion håber og tror derfor, at det udvidede spektrum af fagligheder netop er med til at styrke netværk og inkludere, frem for at ekskludere, alle aktører i grænselandet mellem medicinsk og samfundsvidenskabelig praksis og forskning. Vi tror, at netop den medicinsk-antropologiske faglighed er tilstrækkelig inkluderende til at nå ud til mange og tilstrækkelig solidt udviklet til at give både teoretisk, metodisk og analytisk dybde i artiklerne.

Det viser sig også, at der er en lille gruppe forfattere, som har været ganske aktive med at producere artikler til tidsskriftet og optræder som forfattere 3 eller flere gange. Ikke overraskende er en del af redaktørerne - Hanne Mogensen (5 stk), Jens Seeberg (4 stk), Mette Bech Risør (4 stk), Torsten Risør (5 stk) - på denne liste, da det oftest er os som skriver - eller er med til at skrive - introduktionsartiklerne til numrene; introduktioner som giver en oversigt over temaet og introducerer de følgende artikler og deres perspektiv. Men vi har også fået mange bidrag fra Katrine Johansen (7 stk), Lone Grøn (4 stk), Charlotte Jakobsen (3 stk), Lise Gormsen (3 stk). Betyder det, at der er en skævhed i, hvad der publiceres? Ja, det kan man jo overveje. Det betyder i hvert fald, at der er et sammenfald mellem hvad, der 
publiceres, og de personer som fra starten var redaktører og gæsteredaktører og som investerede en del arbejde i den tidlige fase, hvor tidsskriftet skulle etableres.

\section{"Impact factor"}

Vi startede tidsskriftet, fordi vi mente, at der var et behov for det, fordi vi troede, at det kunne være med til at gøre en forskel. Undervejs i arbejdet blev fokus ofte drevet af nødvendig pragmatisme, når det gjaldt om at få skabt gode temaer, få gode processer og kvalitetskrav omkring artiklerne og at få økonomien til at hænge sammen. Men efter ti år er det også rimeligt at spørge sig selv, om der faktisk var et behov, og om tidsskriftet faktisk har gjort en forskel. Hvordan er vores kvalitative "impact factor", når det gælder de mål, vi satte os?

Var der faktisk et behov for et nyt medicinsk-antropologisk tidsskrift på dansk? Vi kan nærme os svaret fra lidt forskellige steder. For det første ser det ud til, at der er et behov hos forskere for at få formidlet forskning fra feltet. Vi udgivet 21 forskellige temaer, og 143 forfattere har bidraget med artikler. Der er ikke noget fra det arbejde - eller fra arbejdet med planlagte temaer i fremtiden - som tyder på, at feltet er udtømt. Det faglige spektrum - både i temaer og i de fag og miljøer som forfatterne som beskrevet repræsenterer - er bredt og voksende, og det ser derfor ud til, at selvom der nominelt er få som har medicinsk antropologi som overskriften for deres arbejde, så er det medicinsk antropologiske felt åbent for forskere fra mange forskellige fagligheder, som i TFSS kan få mulighed for at præsentere deres forskning som ofte befinder sig i grænsefladen eller overgangen mellem forskellige fag.

Et tidsskrift skal også læses, hvis det skal have en berettigelse. Det kan derfor også være interessant at se på antallet af abonnenter. Det var også helt fra starten en nødvendighed for redaktionen at tænke på, fordi vi økonomisk set var afhængige af abonnementer, og desuden skulle have 200 abonnenter i løbet af de første tre år for at kunne få en ny bevilling fra forskningsrådet. Vi valgte at have både et individuelt abonnement og et lidt dyrere institutionsabonnement. Desuden var og er det muligt at købe enkeltnumre til en pris lidt over det, som abonnenterne betaler.

De første par år var mange af abonnenterne enkeltpersoner som havde en relation til redaktionen eller til masteruddannelsen i sundhedsantropologi. Men gradvist begyndte der også at komme flere institutionsabonnementer, og da forskningsrådet accepterede, at et institutionsabonnement kunne tælles som mere end 
1 abonnement, nåede vi (med denne fortolkning) over grænsen på 200 og kunne få støtte til at fortsætte. I $2006 \mathrm{kom}$ vi første gang over 100 individuelle abonnenter. Institutionsabonnementerne kom som sagt lidt langsommere, men i $2008 \mathrm{kom}$ vi over 50. Status i februar 2015 er, at vi har 125 individuelle abonnenter og 55 institutionsabonnenter.

I 2007 startede universitetsbiblioteket i Århus et projekt som skulle give universitetets tidsskrifter mulighed for dokumentstyring og redaktionel proces via en fælles elektronisk platform kaldet Open Journal System (OJS). Vi deltog i dette og gennem workshops og rollespil, fik vi oprettet en ny hjemmeside, fik en større systematik i processen med kommunikation med forfattere og reviewere og fik oprettet en database med tidligere numre og artikler. Fra og med nr. 12 har den redaktionelle proces foregået via OJS, og selvom det var nyt, har vi i dag et system som fungerer godt - og bedre end tidligere.

Fra 2008 begyndte diskussionerne om open access for alvor. Indtil da var det kun abonnenter som kunne læse vores artikler, men fordi forskningsrådene diskuterede at indføre et krav om open access for at kunne få støtte, blev det pludselig en mere påtrængende diskussion, særlig blandt små tidsskrifter som vores, som var mere sårbare for fald i abonnementsindtægt. Vi diskuterede det i redaktionen og skulle her veje for og imod. En interessant diskussion egentlig: Skulle vi vælge det som mange andre små tidsskrifter så som "det sikre" og holde fast ved, at kun abonnenter kunne læse artiklerne, eller skulle vi vælge det usikre open access ud fra en princip om, at forskning bør gøres tilgængelig for flest mulige? Vi valgte det sidste, men dog med den begrænsning at artikler fra de seneste 2 numre kun kunne læses af abonnenter. Fra 2008 var der derfor adgang til alle artikler som var mere en 1 år gammel og fra 2010 open access til alle artikler.

Da vi gik over til open access, blev spørgsmålet om antal læsere også lidt mere kompliceret, fordi der nu var mange ikke-abonnenter som fik mulighed for at læse artiklerne. Man kunne også frygte, at det måske over tid ville betyde, at vi ikke længere havde abonnenter nok til at udgive en trykt udgave af tidsskriftet.

Fik det betydning for antal abonnenter? Tilsyneladende ikke. Vi havde allerede i et par år haft et nogenlunde konstant antal abonnenter. Hvis det gjorde en forskel, var det måske endda til vores fordel med en lille stigning og derefter stabilt antal. Til gengæld betød det nu, at der var flere, der læste og refererede artiklerne. Vi har først for nylig fået mulighed for statistik på hjemmesiden, men vi kan se, at vi i dag har 444 registrerede brugere på hjemmesiden, altså en langt større kreds end dem vi nåede ud til i de første år, og altså også et stort antal personer som rækker udover kredsen af forfattere eller reviewere. 
Det var lidt kvantitativt om brugen af tidsskriftet, men det er klart, at det også er interessant $\mathrm{i}$ hvilke sammenhænge, læsningen indgår, og i hvilke processer artikler bliver brugt. Her er det lidt vanskeligere at få et samlet billede, men nogle pejlemærker har vi trods alt. Vi ved, at artikler allerede fra de første temanumre (specielt nr. 1,2 og 4) er brugt som pensum i uddannelsesprogrammer (herunder på sygeplejerskeuddannelser, master i humanistisk sundhedsvidenskab og master i sundhedsantropologi). Vi ved også, at enkelte numre har haft et større løssalg (specielt nr. 3) og altså har appelleret til et publikum, som ellers ikke er faste læsere. Vi ved, at artikler er blevet brugt i faglige og politiske beslutningsprocesser, og vi har enkelte gange efter aftale med både forfatter og reviewer ophævet forfatterens anonymitet før udgivelsen af artiklen, fordi der var behov for et samarbejde. Det gjaldt eksempelvis Høyers artikel i nr. 11 (2009), hvor den ene reviewer var med i et arbejde i EU som skulle udvikle retningslinier for knogletransplantation. Fire temaer er resultatet af videnskabelige konferencer (nr. 10, 13, 17, og 19), og har dermed været med til at sikre en samlet præsentation af temaer, som ellers ville være begrænset til de som deltog på konferencerne. Publicering af konference-temaer blev muligt, fordi vi valgte at åbne for at udgive temaer på engelsk, og som det også viser sig i listen over forfattere, var det med til at få nye stemmer og miljøer repræsenteret på tidsskriftets sider.

Indtil videre har tidsskriftet ikke været indekseret i de litteraturdatabaser som bruges mest - hverken de samfundsvidenskabelige eller de sundhedsvidenskabelige. Set på den baggrund er vi egentlig godt tilfredse med, at vi bliver læst og brugt så meget, som vi gør. Men det er klart, at en øget tilgængelighed også kan være med til at forfatternes arbejde bliver læst og brugt mere, og det er selvfølgelig højt på redaktionens ønskeliste. En væsentlig hindring er, at et tidsskrift skal citeres på et vist niveau for at kunne blive indekseret, mens det samtidig er de indekserede tidsskrifter, som gennem tilgængelighed lettest kan blive citeret. Det er en udfordring, som vi i den nuværende redaktion må arbejde mere med, og hvor vi sikkert også er lidt begrænset af, at vi ikke i redaktionen har forskningsbibliotekarens kompetence - og heller ikke har haft tid til at arbejde målrettet med dette. Tidsskriftet lever op til alle de kvalitetskrav som ellers stilles til eksempelvis peer review, og den interesse og bredde, som vi trods alt har, tyder på, at vi bør prøve at nå ud til en større kreds gennem relevant indeksering. 


\section{Ønsker for fremtiden}

Det fører frem til overvejelser om, hvilken vej TFSS skal styre i fremtiden. Vi kan jo starte med at se på, hvor langt vi er kommet med de ambitioner, vi lagde i den første beskrivelse af tidsskriftet (se ovenfor): Vi ønskede at formidle medicinsk antropologi, der er relevant i en bredere sundhedsmæssig sammenhæng. Ud fra temaer og læserskare ser det ud til at være lykkedes. Vi ønskede at formidle anden faglig forskning, der bidrager til diskussioner inden for det medicinsk antropologiske interessefelt. Det har vist sig, at mange fagligheder ser tidsskriftet som et relevant sted at publicere, og derigennem mener vi også, dette er lykkedes. Vi ønskede at udkomme som temanumre, og at hvert tema skulle belyses fra flere forskellige faglige perspektiver. Det har vi gennemført både i spektret af forfattere og reviewere, og det kommer vi til at fortsætte med. Vi ønskede at formidle forskning på et højt fagligt niveau. Når vi ser på listen over forfattere og reviewere, når vi ser på listen over temaer og artikler, når vi ser på brugen af tidsskriftet, så tillader vi os at tro, at vi er kommet et stykke på vej også med den ambition.

Men det kan jo også være anledning til at sætte sig nye mål, og det har vi også gjort. Den nuværende redaktion ønsker at nå ud til en større kreds, så artiklerne bliver læst af flere, og flere forskere får mulighed for at publicere deres resultater. $\mathrm{Vi}$ har taget skridt i retning af at blive et mere skandinavisk og nordisk orienteret tidsskrift, og det kommer vi til at arbejde videre med. Hvis vi lykkes med at blive indekseret i løbet af de næste par år, vil det være med til at styrke den bevægelse. Det vil også udvide muligheden for at bringe temaer, hvor der er for få forskere i de danske miljøer. Vi vil altså kunne præsentere synteser af forskning som ikke har sine egne miljøer, og hvor måske derfor kan være særligt brug for at få en samlet præsentation.

Det er sandsynligt, at nye udviklinger - fagligt og politisk - vil få indflydelse på tidsskriftet, og de temaer vi vælger. Udviklingen i medier og publikationsregler var med på at skabe OJS og open access. Vi tror, vi traf nogle rigtige valg, men vil vi fortsat ramme rigtigt i fremtiden? Aktuelle diskussioner indenfor sundhedsvæsenet har været med til drive nogle temaer frem, særligt hvor vi mente, at der var behov for et kritisk perspektiv på sundhedspolitiske strømninger. Det gjaldt både for nogle af de tidlige numre om sundhedsfremme (nr. 3), om psykiatri (nr. 4), og det gælder nogle af de seneste numre om evalueringer (nr. 15) og dette nummer om brugerperspektivet. I nogle tilfælde har vi valgt temaer, hvor vi netop så, at opmærksomheden gik i andre retninger, og vi ønskede at kaste lys over problemstillinger som var overset. Det gælder bl.a. temaerne om somatisering (nr. 5), 
om etniske minoriteter (nr. 7) og om døden (nr. 12). Med nogle temaer har vi også forsøgt at vælge nogle kategorier som ikke overholder faggrænser, for bevidst at udfordre hvor grænserne går og forhåbentlig åbne for en tværfaglighed, som vi har set et behov for i aktuelle diskussioner i forskningen og i sundhedssystemer generelt. Temaerne om krop \& teknologi (nr. 11), at spise (nr. 14) og arbejde (nr. 16) er eksempler på det.

Er det lykkedes at vælge temaer som tager højde for aktuelle bevægelser i sygdom og samfund; temaer som kaster lys over det underbelyste; temaer som udfordrer begrænsende kategorier og faggrænser? Det må være op til andre at vurdere. Men ambitionen har vi fortsat. Vi vil blive ved med at forsøge at have fornemmelse for, hvilke temaer som har et særligt potentiale eller en særlig aktualitet. Vi vil fortsætte med at vælge temaer som lægger op til inspiration på tværs af faggrænser og mulighed for nye samarbejder, og vi vil også fortsat stræbe efter at trække temaer frem, som vi mener, er overset i forskningen eller i politiske processer. Vores ambition og drivkraft i starten var, at vi ikke bare ville være deskriptive rapportører af, hvad der foregik i det medicinsk antropologiske felt, men også have en refleksiv tilgang til det og fokusere på temaer, som vi synes fortjener en kritisk analyse. Det gælder for det nummer, som du sidder med nu om brugerperspektivet, og det gælder for de planlagte temaer om placebo (nr. 23), emotioner (nr. 24) og diagnosen (nr. 25).

\section{Tak!}

Vi vil gerne fra redaktionen sige en stor tak til alle som har bidraget til de første ti år med Tidsskrift for Forskning i Sygdom og Samfund. Tak til tidligere redaktører, tak til gæsteredaktører, tak til vores solide redaktionssekretærer, tak til forfattere, tak til vores reviewere og tak til alle jer som abonnerer og læser resultatet. Der er en del arbejde i at være i redaktionen, men det er berigende og inspirerende at samarbejde med jer, og vi er meget taknemmelige for, at I tror på projektet og er med til, at det vokser og gror.

Det var vores status over arbejdet som startede med en ide i 1999, og nu er et tidsskrift med udgivelser gennem 10 år og over 400 brugere. Vi glæder os til at arbejde videre med at udvikle projektet, og har du en ide til et tema eller en artikel, er du velkommen til at kontakte redaktionen. God fornøjelse med kommende numre af Sygdom \& Samfund. 